\title{
Phenology and Vegetative Growth in a New Production Region of Grapevines: Case Study in São Joaquim, Santa Catarina, Southern Brazil
}

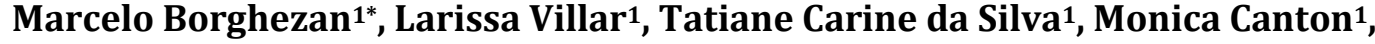 \\ Miguel Pedro Guerra ${ }^{1}$, Claudia Guimarães Camargo Campos ${ }^{2}$ \\ ${ }^{1}$ UFSC-Universidade Federal de Santa Catarina, Florianópolis, Brazil \\ ${ }^{2}$ UDESC-Universidade do Estado de Santa Catarina, Lages, Brazil \\ Email: mborghezan@hotmail.com
}

Received 25 March 2014; revised 25 April 2014; accepted 29 April 2014

Copyright (C 2014 by authors and Scientific Research Publishing Inc. This work is licensed under the Creative Commons Attribution International License (CC BY). http://creativecommons.org/licenses/by/4.0/

(c) (i) Open Access

\section{Abstract}

In Brazil winemaking is expanding not only in the renewal of vineyards in traditional production areas, but also in the introduction of new crops in the newer winemaking regions. Promising characteristics were observed in the quality of the grapes and wines produced in altitude regions of Santa Catarina. The aim of this study is to characterize the geographic and climatic conditions which affect the phenology and vegetative growth of grapevine in São Joaquim, in the mountains region of Santa Catarina. The vineyards are located in areas with undulated and strongly undulated relief, predominantly in soils originating from basaltic rocks, in climate conditions classified as $C f b$ according to the Köppen, as Region I according to Winkler classification. The phenological stage of the grapevines in the São Joaquim region begins later and lasts longer in comparison to other winegrowing regions in Brazil. Decrease in photoperiod and low temperatures $\left(<10^{\circ} \mathrm{C}\right)$ were the determining factors for the induction of growth cessation of the shoots in São Joaquim. The geographic location in a lower latitude and its high altitude results in a distinct growing climate compared to the other winegrowing regions in Brazil.

\section{Keywords}

Vitis vinifera L., Climate Characterization, Phenological Events, Ecophysiology

\footnotetext{
${ }^{*}$ Corresponding author.
}

How to cite this paper: Borghezan, M., et al. (2014) Phenology and Vegetative Growth in a New Production Region of Grapevines: Case Study in São Joaquim, Santa Catarina, Southern Brazil. Open Journal of Ecology, 4, 321-335. 


\section{Introduction}

Winemaking is an important economical and touristic activity that generates jobs and income distribution. Wines have a strong relation with the local aspects and the cultural means of production, which gives them a regional identity that is referred to by the French term terroir [1], and nowadays hundreds of winegrowing regions in the world are characterized.

Winegrowing in Brazil currently occupies 81,915 hectares of cultivated area, and in 2011 the country’s grape production was around 1.46 million tons [2]. The industry is based on the production of grapes to be consumed fresh (table grapes) and as juices and wines, among other products. This activity is expanding and in recent years the vineyards have been improved in order to produce better quality grapes and wines. The country's wine production is concentrated mainly in the states of Rio Grande do Sul and Santa Catarina, which are responsible for over $90 \%$ of the national production [2], and also in the Vale do São Francisco region, located between the states of Pernambuco and Bahia.

In Santa Catarina, the cultivated area is currently 5009 hectares, and in 2011 the state's production was 67,767 tons [2]. Along with Rio Grande do Sul, the regions where winemaking is traditionally established have an agrarian structure that is based on family farming, established on small properties located on steep topography. The cultivation of grapevines on these properties is strongly linked to Italo-Brazilian communities, and it is predominantly characterized by the use of American grapes (Vitis labrusca L.) and hybrid varieties for the production of table wine and grape juice. The cultivation of European varieties (Vitis vinifera L.), intended for the production of fine wines, is smaller; however, this cultivation is expanding not only in the renewal of vineyards in traditional production areas, but also in the introduction of new crops in the newer winemaking regions in Brazil.

The traditional cultivation areas for wine production (Serra Gaúcha, RS and Vale do Rio do Peixe, SC) have high relative humidity, high temperatures, and high levels of precipitation during the growth cycle of the plants, which are features that classify these regions as Temperate Warm and Humid with Temperate Nights [3]. These conditions hinder the cultivation of different wine grape varieties, mostly by favoring the incidence of fungal diseases and leading to early harvesting. These factors contributed to the settlement of vineyards in places with different characteristics, such as the Vale do São Francisco, between the states of Pernambuco and Bahia, and more recently the Campos de Cima da Serra and the Campanha regions in Rio Grande do Sul state, as well as the Planalto Serrano region in Santa Catarina state.

Findings on the qualitative characteristics of wines made from Cabernet Sauvignon grapes cultivated at higher altitudes (>900 $\mathrm{m}$ above sea level) have encouraged the development of viticulture in the Planalto Serrano region of Santa Catarina, which is now a fine wines production hub [4].

Many researchers [5]-[8] have reported that grapes grown in São Joaquim have their own characteristics, which differ from the grapes grown in other winegrowing regions in Brazil. The soil and climate conditions prolong the phenological stage, thereby favoring a more complete ripening of the grapes and better development of the compounds of interest [4]. The wines made from grapes grown in the São Joaquim region have different characteristics, such as greater color intensity and higher content of total phenolics and anthocyanins, in comparison to wines made from grapes cultivated in other winegrowing regions in Brazil [9].

Commercial cultivation of grapes in the Planalto Serrano region began in 1999 and currently this region has utilized over 300 hectares of cultivated land. São Joaquim is the main production hub, where there are the highest number of winegrowers and the largest cultivated area (Figure 1). Within the main varieties produced, Chardonnay and Sauvignon Blanc stand out among the white grapes, and Pinot Noir, Merlot, Cabernet Franc, Cabernet Sauvignon, and Sangiovese among the red grapes.

The aim of this study is to characterize the geographic and climatic conditions which affect the phenology and vegetative growth of grapevine in altitude regions of Santa Catarina.

\section{Material and Methods}

The evaluations were realized in an area of commercial production in São Joaquim, Santa Catarina, Brazil. The vineyard of Cabernet Sauvignon, Merlot and Sauvignon Blanc varieties was located in an altitude of 1293 m, latitude $28^{\circ} 15^{\prime} 13^{\prime \prime} \mathrm{S}$ and longitude $49^{\circ} 57^{\prime} 02^{\prime \prime} \mathrm{W}$. Planting was realized in 2002, and the plants were grafted over the Paulsen 1103 rootstock, conducted in vertical trellis system, spaced 3.0 meters between lines and 0.75 meters between plants, with N-S orientation. The weather was classified as $C f b$, according to Köeppen’s classification. 

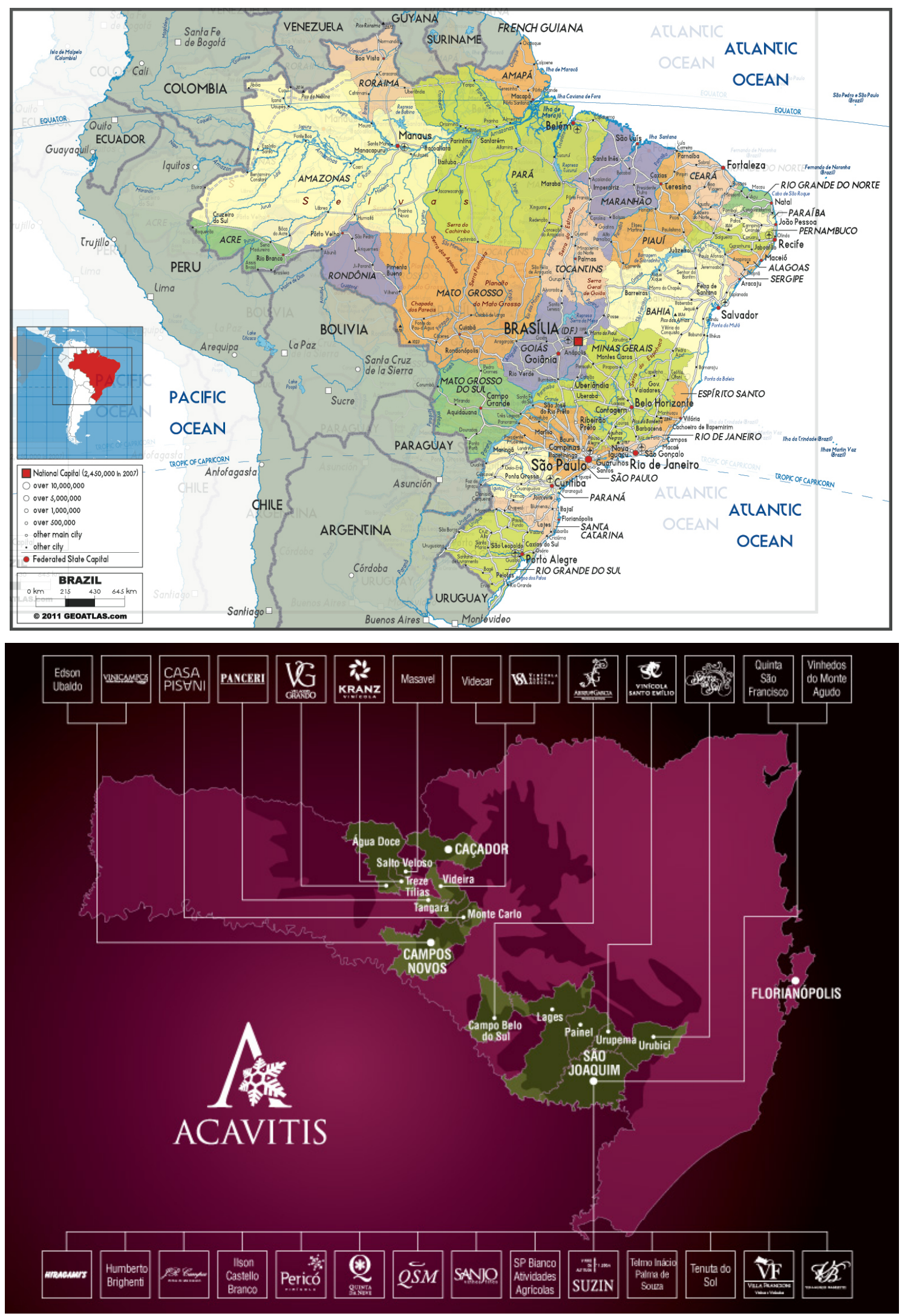

Figure 1. Altitude of winegrowing regions in Santa Catarina ( $>900 \mathrm{~m}$ above sea level), Brazil. 
Since the budburst, the shoots were conducted in the vertical position to a better canopy disposition. The pruning was realized leaving 2 buds per spur, in a unilateral spur system.

The meteorological data were obtained from a meteorological station located at vineyard. The daily data of precipitation, temperature (minimum, medium and maximum) and photoperiod were accomplished and obtained from CIRAM (Center of Environmental Resources Information and Hydrometeorology of Santa Catarina). The thermoperiod (daily thermical amplitude) was estimated through the difference between maximum and minimum temperatures. Thermal sum (degree days) was estimated using base temperature for vine $\left(10^{\circ} \mathrm{C}\right)[10]$. The historical dates were obtained from a meteorological station located at Epagri Experimental Station (Company of Research and Rural Extension of Santa Catarina) at $1415 \mathrm{~m}$ of altitude and far away $2800 \mathrm{~m}$ from the experimental area. The climate characterization in this study was performed with that meteorological database as reference, considering the time period from 1961 to 2011.

The phenology was evaluated according to [11]. In order to define the phenological stages of the grapevine it was used the BBCH scale (Lorenz et al., 1995). The phenological stages described were: budburst (BBCH 07), flowering (BBCH 65), véraison (BBCH 85), and harvest.

The shoot growth was evaluated since the random selection of 20 buds (1 per spur) in the medium region of the plants. The shoots were identified and evaluated since the beginning of the development (budburst), measuring from the shoot insertion base to the apical meristem. The evaluations were realized with a fillet following the shoots curvatures during the vegetative growth. It was estimated the growth medium rate to each of the evaluated period and to the total growth cycle from the collected data [12].

The experimental design used was totally randomized, composed by twenty repetitions (shoots). The data were evaluated using Statistica version 6.0 software through the polynomial regression analysis, within $5 \%$ of error probability.

\section{Results and Discussion}

\subsection{Characterization of the Planalto Serrano Region in Santa Catarina}

\subsubsection{Geographic Location}

The Planalto Serrano region in Santa Catarina comprehends not only the state's highlands, but also part of its western and northern regions, where there are mountains as high as 1827 meters. The predominant climate is subtropical, and during the winter the occurrence of frost is frequent and snowfalls are very occasional.

The main factor that influences the quality of the grapes produced in the São Joaquim region is its climate, classified as $C f b$ according to the Köppen classification. Among the main features associated with and that directly influence on the climatic variables are: the region's proximity to the Atlantic Ocean ( 150 km), high altitude (1200 to 1400 meters above sea level), low latitude $\left(28^{\circ}\right)$, well-defined seasons that feature cold winters and mild summers, besides the action of different weather systems throughout the year.

In general, the vineyards are located in areas with undulated and strongly undulated relief, predominantly in soils originating from basaltic rocks, classified as Humic Cambisol (Figure 2). These soils are well drained and have stones in the surface layers; they are shallow and are still in their original condition, showing low fertility, high organic matter content, high acidity levels, and aluminic character. Regarding their physical characteristics, these soils generally have a silty clay texture and a dark brown color, and they are soft and friable and show high water retention capacity.

\subsubsection{Climate Characterization}

Located in a region of humid subtropical climate, $C f a$ and $C f b$ according to the Köppen classification, the state of Santa Catarina is characterized by large climate variability between its different regions, particularly because of its geographical position, the configuration of its relief, and the action of different weather systems. Unlike other regions of Brazil, Santa Catarina is marked by seasonal peculiarities, i.e., it has four distinct seasons (summer, autumn, winter, and spring), and it shows great variation in temperature and evenly distributed rainfall throughout the year. It is important to note that the prevailing atmospheric seasonal patterns can be altered by interannual climate phenomena, such as the ENSO (El Niño-Southern Oscillation) and by extreme adverse events [13].

Climate-modifying factors contrast between the different regions of Santa Catarina, causing the existence of regions with distinct climatic characteristics, and thus making them favorable for certain economical activities. 
São Joaquim, located in the Planalto Sul region of Santa Catarina, is an example of such diversity, with climatic peculiarities that are typical of its geographic location and its high altitude. Such weather conditions have favored the big boost in the cultivation of temperate fruits, highlighting São Joaquim in the fruit production scenario in Santa Catarina. Its wine production has become nationally and internationally distinguished, not only in relation to the cultivation of the grapevines but also to the production of fine wines. In many winegrowing regions, the climate is a natural factor that determines the regional potential for adaptation of varieties as well as the quality and typicality of wine production.

Daily data from the weather station in São Joaquim, located at 1376 meters above sea level $\left(28^{\circ} 16^{\prime} 31\right.$ "S, $49^{\circ} 56^{\prime} 03^{\prime \prime} \mathrm{W}$ ) and monitored by the Ciram (Center for Information on Environmental Resources and Hydrometeorology in Santa Catarina), which is a department of the Epagri (Company for Agricultural Research and Rural Extension in Santa Catarina), show the characteristics of temperature and relative humidity in this area and how other meteorological variables fluctuate throughout the year. The climate characterization in this study was performed with that meteorological database as reference, considering the time period from 1961 to 2011 (Table 1).

In São Joaquim the climate is $C f b$ (temperate-mesothermal humid and mild summers), according to the Köppen classification. The main climate characteristics are the low temperatures in winter (record of $-10^{\circ} \mathrm{C}$ in August 1991) and warmer temperatures in the summer, with a maximum record of $31.4^{\circ} \mathrm{C}$ (Table 1). It is considered one of the coldest places in Brazil, where the average air temperature is $13^{\circ} \mathrm{C}$. July is the coldest month of the year, showing average temperatures around $9.4^{\circ} \mathrm{C}$, and the month of January is the warmest, with an average temperature of $17^{\circ} \mathrm{C}$ (Figure 3). The annual temperature range in São Joaquim is $9.4^{\circ} \mathrm{C}$. Rainfall is evenly
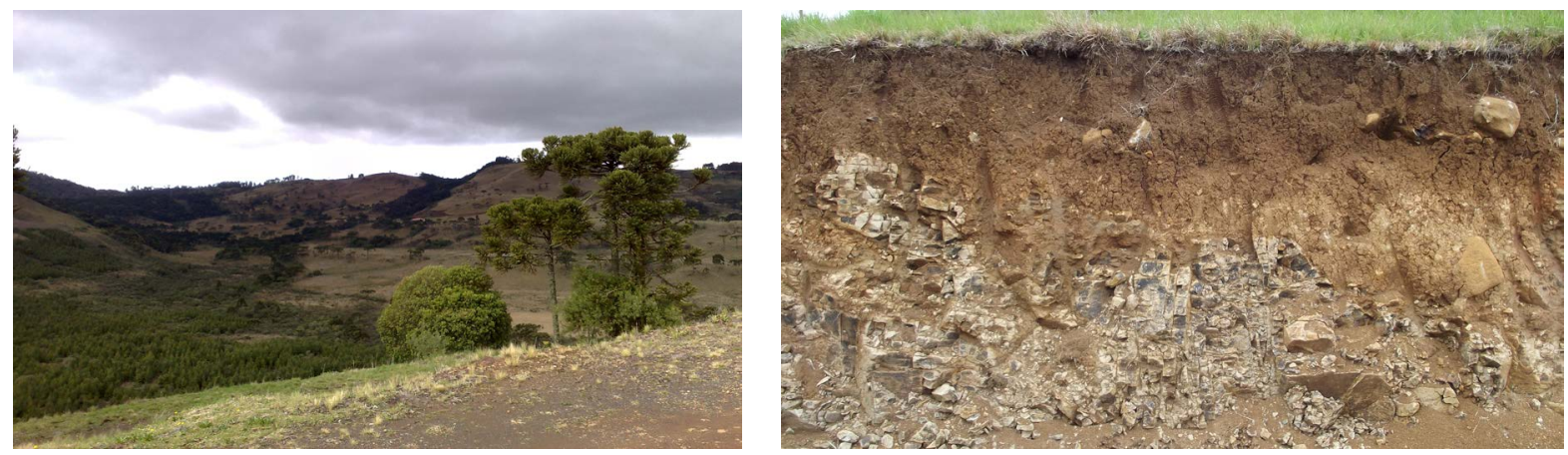

Figure 2. At the left, landscape showing the relief and the native vegetation (Araucaria moist forest), and at the right the soil profile. São Joaquim, Santa Catarina, Brazil.

Table 1. Characterization of the annual climate in São Joaquim, SC, Brazil.

\begin{tabular}{cccc}
\hline Variable & Unit & & Value \\
\hline Climate (Köppen) & \multicolumn{3}{c}{$\mathrm{C} f b$-Temperate } \\
\hline Rainfall & $\mathrm{mm}$ & Mensal mean & 147.0 \\
Minimum temperature & ${ }^{\circ} \mathrm{C}$ & & 9.4 \\
Medium temperature & ${ }^{\circ} \mathrm{C}$ & & 13.3 \\
Maximum temperature & ${ }^{\circ} \mathrm{C}$ & Annual mean & 18.8 \\
Relative humidity & $\%$ & & 79.0 \\
Medium temperature & ${ }^{\circ} \mathrm{C}$ & Oct-Apr & 15.5 \\
Cold hours & $\sum$ Hours $\left(\mathrm{T}<7.2^{\circ} \mathrm{C}\right)$ & & 1057.4 \\
Frost occurrence & $\mathrm{days}$ & & 13 \\
Minimum temperature & ${ }^{\circ} \mathrm{C}$ & & -10.0 \\
Maximum temperature & ${ }^{\circ} \mathrm{C}$ & Absolute value & 31.4 \\
Maximum rainfall in 24 hours & $\mathrm{mm}$ & & 204.6 \\
\hline
\end{tabular}




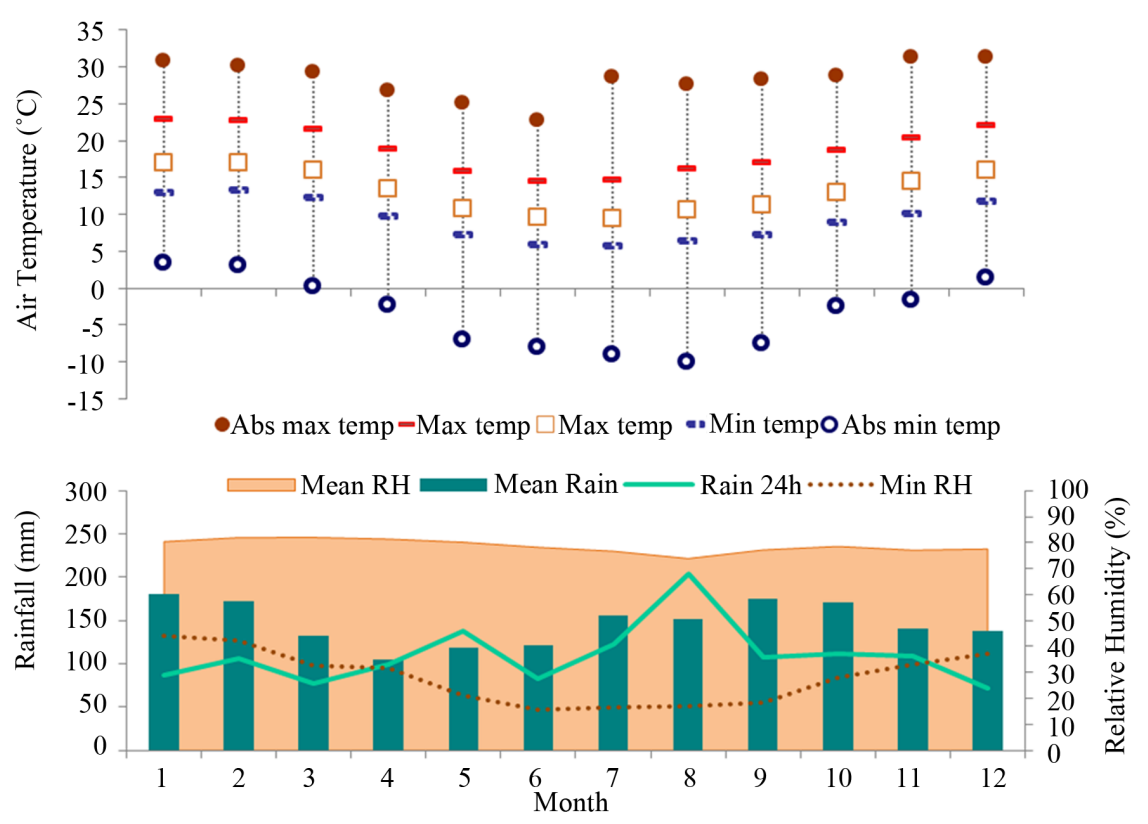

Figure 3. Monthly mean of air temperature $\left({ }^{\circ} \mathrm{C}\right)$ - maximum, medium, and minimum, rainfall (mm) and relative humidity (\%) for São Joaquim, Santa Catarina, Brazil (period considered: 1961 to 2011).

spread throughout the year, without occurrence of a dry season as in other regions of Brazil. The period from March through June is when there is least rainfall in São Joaquim, with monthly precipitation ranging between 105 and $122 \mathrm{~mm}$. The variation in relative humidity shows a monthly average that ranges between $74 \%$ and $82 \%$, with daily minimum humidity rates around $16 \%$, recorded in the winter months when polar masses are acting. It is from this time on that the weather conditions begin to be influenced by frequent incursions of cold air masses in Santa Catarina, which sharply decrease air temperature and sustain drier weather conditions.

During the winter months, occurrence of frost is common and on colder days there are occasional snowfalls. However, the period between the months from May through August is also characterized by occasional spells of higher temperatures, commonly referred to as "Veranico" (Indian summer). On these occasions, the cold fronts are diverted from their usual route through Santa Catarina, moving towards more southerly latitudes and causing consecutive days with no rain and with temperatures that are higher than usual for that time of year. In September, the climate condition is the transition from winter to spring, with the onset of tropical air mass activity. The days are warm, but there are still intense and frequent cold air masses acting.

The largest volumes of rainfall occur in the months of September and October, climatologically the wettest months in the state of Santa Catarina. In São Joaquim there are also summer rains in the months of January and February, with monthly totals of $180 \mathrm{~mm}$ and $173 \mathrm{~mm}$, respectively. During this time of the year, the intensity of the heat associated with high levels of humidity favors the formation of tropical convection, which consists of bands of cumulonimbus clouds and consequently generate more intense rainfall, especially in the afternoons.

An analysis of the monthly distribution of total days with temperatures below $0.0^{\circ} \mathrm{C}$ showed that the months of June and July had a higher frequency of frost occurrence (Figure 4). In the months of autumn and spring there may be occurrence of temperatures below $0^{\circ} \mathrm{C}$, especially in the spring, where there have been frequent cases of late frosts. Moreover, it is in the winter months that the total of accumulated chilling hours (sum of hours with $\mathrm{T}<7.2^{\circ} \mathrm{C}$ ) is higher, with greater occurrence in July, where the average is 240 hours. Between the months of April and September, the average of total accumulated chilling hours is 1057.4. The average monthly photoperiod in São Joaquim ranges from 11 to 15 hours.

According to the description above, the main climate characteristics in São Joaquim are low air temperatures, high availability of chilling hours, and its rainfall pattern, which is regular throughout the year, being a little more frequent in spring and summer. Except the high frequency of frosts during spring, such features are propitious for the cultivation of wine grapes. 


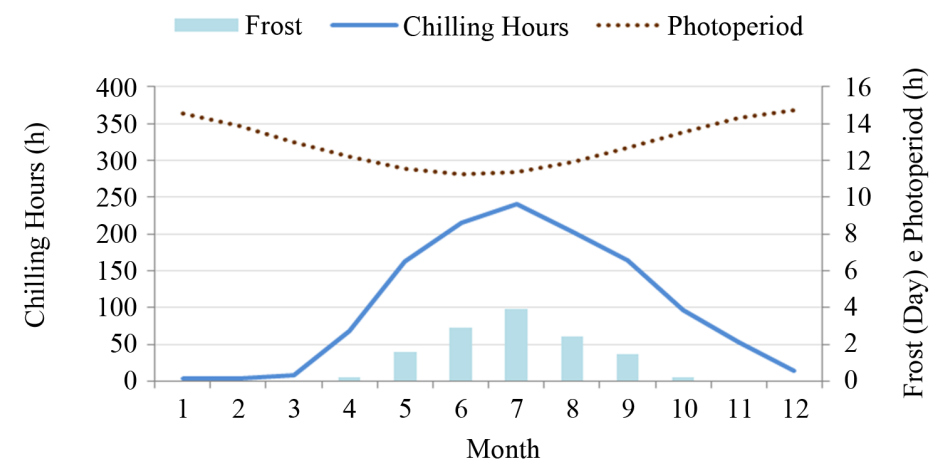

Figure 4. Monthly chilling hours, occurrence of frost days and photoperiod for São Joaquim, Santa Catarina, Brazil (period considered from 1961 to 2011).

\subsection{Phenology}

Monitoring the growth stages of the grapevines to characterize their stages of development is a way to determine the adaptation of plants to the cultivation region [14]. It also enables the planning of management activities, the determination of varietal differences, the differentiation between production regions, and the estimation of ideal harvesting time [15]. The behavior of the vines (phenology, growth, yield, and quality of grapes) also varies between growing seasons and is mainly affected by weather conditions in each particular cycle. These variations alter phenology, plant growth, and characteristics of the grapes and they reflect on the composition and sensory attributes of wines [11].

The time interval between the onset of budbreak and the falling of the leaves defines the vegetative cycle of the vines, which is divided into various growth stages according to the models proposed by Baillod and Baggiolini, Eichhorn and Lorenz, and Coombe [16] and the BBCH-scale [17]. The time the plants remain with no metabolic activity or with no visible growth defines their dormant period or dormancy stage [18].

Determination of the growth stages is performed visually, and the growth cycle can be divided into three main stages [11] [15]. Budbreak, which begins at the mobilization of the reserves accumulated in stems and roots, is the initial development phase of the shoots and leaves and, afterwards, of the floral structures. During this period, the plants start photosynthetic activities, transitioning from a heterotrophic phase to an autotrophic phase stages [15]. The stages of flowering and fruit set constitute a second important phase of the phenological stage of the grapevine. After pollination and fruit set, the formation of berries progresses with increase in size, resulting from cell division (increase in number of cells) and accumulation of reserves (increase in cell volume) [19]. The third phase is the ripening stage, which begins when berries change color and/or soften (veraison) and goes on until harvesting. In this phase, there are many physical and biochemical transformations that alter the color, consistency, size, and chemical and aromatic composition of the berries [19].

In São Joaquim, budbreak occurs in September (Table 2) and the earliest varieties, such as Chardonnay and Pinot Noir, may start budbreak in August. These observations were also described by [20], who evaluated 10 varieties of grapes grown in São Joaquim. This behavior may contribute to the damage caused by late frosts, which occur with low frequency until the month of October and may impair growth and production.

Flowering occurs from mid November through early December and is more common in late November. Ripening begins between late January and early February, about 70 days after full bloom (Table 2). The Sauvignon Blanc and other earlier varieties, such as Chardonnay and Pinot Noir, are harvested in February or March. The red varieties are harvested in April, and the variety Cabernet Sauvignon is usually harvested after the Merlot. The rainfall in these two months is smaller and the milder temperatures contribute to more adequate conditions for berry ripening, and thus enable further progress in the sugar/acidity relation and phenolic maturation. Later varieties can be harvested as late as the end of May.

The variety Sauvignon Blanc has the shortest cycle in relation to the Merlot and Cabernet Sauvignon. There are small variations among the years in the period between budbreak and véraison and the largest differences between cycles occur in the ripening period. The Sauvignon Blanc has an average cycle of around 170 days, while the Merlot and Cabernet Sauvignon have a total cycle of over 200 days (Figure 5). The phenological stage 
Table 2. Dates of phenological events for grapevine varieties in different seasons.

\begin{tabular}{cccc}
\hline & \multicolumn{3}{c}{ Season } \\
\hline & $2005 / 2006$ & $2006 / 2007$ & $2011 / 2012$ \\
\hline Budbreak & $09 / 23 / 2005$ & $09 / 22 / 2006$ & $09 / 23 / 2011$ \\
Flowering & $11 / 30 / 2005$ & $11 / 20 / 2006$ & $11 / 15 / 2011$ \\
Veraison & $02 / 16 / 2006$ & $01 / 31 / 2007$ & $02 / 01 / 2012$ \\
Harvest & $03 / 16 / 2006$ & $03 / 14 / 2007$ & $03 / 14 / 2012$ \\
& & Merlot & \\
\hline Budbreak & $09 / 16 / 2005$ & $09 / 18 / 2006$ & $09 / 25 / 2011$ \\
Flowering & $11 / 17 / 2005$ & $11 / 21 / 2006$ & $11 / 15 / 2011$ \\
Veraison & $02 / 08 / 2006$ & $01 / 31 / 2007$ & $02 / 13 / 2012$ \\
Harvest & $04 / 06 / 2006$ & $04 / 03 / 2007$ & $04 / 23 / 2012$ \\
& & Cabernet Sauvignon \\
\hline Budbreak & $09 / 13 / 2005$ & $09 / 15 / 2006$ & $09 / 20 / 2011$ \\
Flowering & $11 / 30 / 2005$ & $11 / 21 / 2006$ & $11 / 15 / 2011$ \\
Veraison & $02 / 10 / 2006$ & $01 / 31 / 2007$ & $02 / 13 / 2012$ \\
Harvest & $04 / 27 / 2006$ & $04 / 17 / 2007$ & $04 / 23 / 2012$ \\
\hline
\end{tabular}

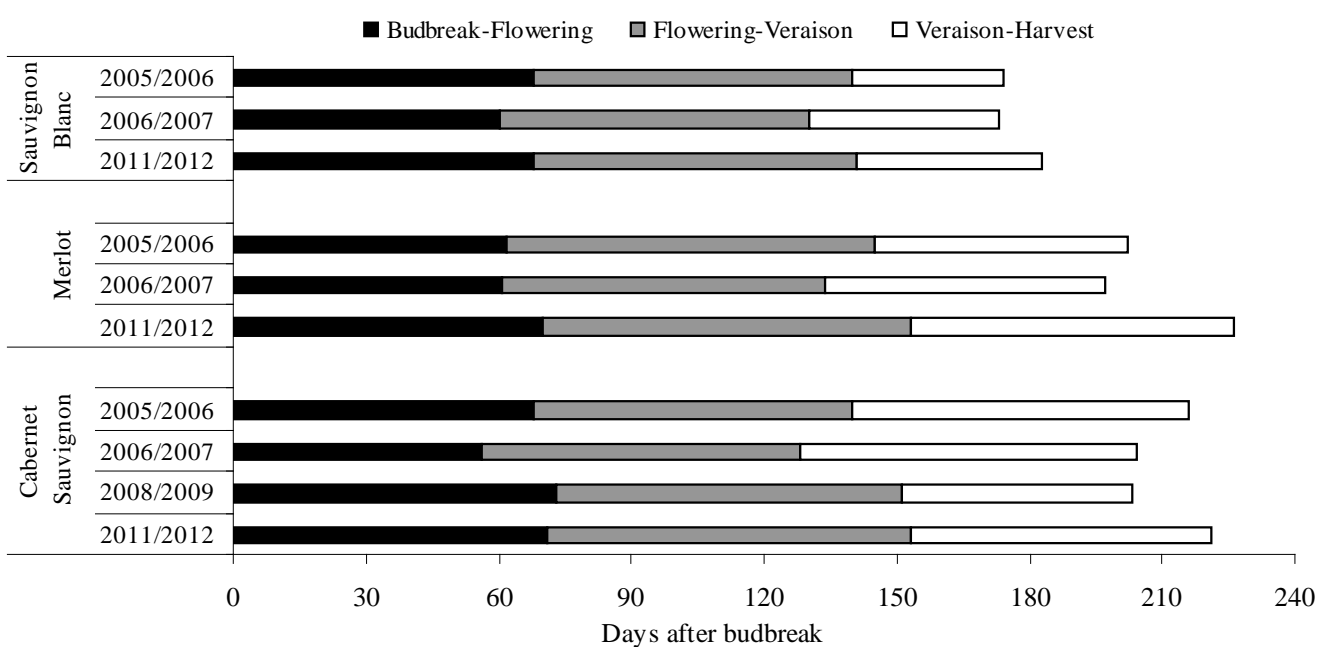

Figure 5. Duration of phenological events in different seasons.

of the grapevines in the São Joaquim region begins later and lasts longer in comparison to other winegrowing regions in Brazil. [21] [22] noted a mean cycle of 150 - 160 days for Merlot and Cabernet Sauvignon grown in Bento Gonçalves, RS. The results of this present study are also in accordance with the observations reported by [14] in Bordeaux/France, where the cycle for the varieties Merlot and Cabernet Sauvignon was approximately 200 days. The thermal conditions during the growth cycle of the grapevines in the São Joaquim region are defined by Jones (2012) as the most suitable for the production of high quality wines for the main varieties (Intermediate: $15^{\circ} \mathrm{C}$ to $17^{\circ} \mathrm{C}$ ). This author classified the varieties in different climate groups, establishing conditions between $13^{\circ} \mathrm{C}$ and $21^{\circ} \mathrm{C}$ as the most appropriate for cultivation of wine grape varieties. 
According to the Winkler classification of winegrowing regions, the vineyards located in São Joaquim are within the boundaries of Region I, with cold weather ( $<1371$ GDD (growing degree days)). The initial growth phase had the lowest thermal sum in all the cycles that were evaluated (Table 2). A higher thermal sum was noted in the period between flowering and early ripening, which corresponds to the warmer months of the year. Values of 1380 GDD were estimated by [5] for this region. These values are below those obtained for the Serra Gaúcha region (1553 GDD) [21], which is the main winegrowing region in Brazil.

A comparison of the phenological stages shows that in 2005/2006 and 2011/2012 the volume of rainfall between September (budbreak) and April (harvest) was lower than $800 \mathrm{~mm}$ (Table 3). In both cycles, the grapes were harvested at advanced stages of ripening, showing high quality and sanity. Other cycles showed total accumulated rainfall above the historic average in São Joaquim for this time of the year, which is approximately $1.115 \mathrm{~mm}$. The 2008/2009 cycle also had little rainfall, and thus provided good ripening.

In general, the ripening period is of less rainfall compared to other periods of the phenological stage, except in the 2006/2007 cycle. In that cycle, both the number of rainy days (46) and the volume of rainfall (449 mm) favored the development of diseases (grape rot) that undermined the quality of the grapes. Observations reported by other authors for the same region [4] [5] [8] also show a decrease in rainfall during the months of ripening (March to April) in different growing cycles.

\subsection{Vegetative Growth}

\section{Shoot Growth}

The vegetative cycle of grapevines begins at budbreak and ends at the end of the growth phase, when the plants cease growth and the dormancy stage begins [18]. The vegetative growth phase depends on several factors, but climate variables play a fundamental role in controlling the development of the grapevines [23]. Keeping balance between vegetative growth (leaves), production capacity (bunches), and the accumulation of nutrient reserves (shoots and roots) favors the physiological processes of ripening [24].

Depending on climate conditions, vegetative growth of the shoots ceases during the phenological stage of berry color change (véraison), as noted by [11] [25]. This behavior favors the transference of photosynthesis compounds, preferably for the formation and ripening of the bunches [19] and for accumulation of reserves in the shoots and roots. When they have excessive growth vigor, grapevines do not cease growth, and the shoots may compete with the bunches for photoassimilates until harvesting season [26].

Shoot growth cessation is a complex physiological behavior that is still not well understood in relation to the biochemical changes in the internal tissues or to meteorological variables responsible for growth cessation [23] [27] [28]. Several authors have reported that temperature and availability of water and nutrients induce shoot growth cessation [11]. Moreover, the photoperiod is also related with growth cessation, as noted by [23] [28], and possibly the thermoperiod as well [29]. This behavior requires halting of cell division in the apical meristem and cessation of elongation of the internodes [23] [30]. Recently, it has been suggested that microclimatic changes act synergistically and induce the hormone regulating biochemical pathways that trigger the cessation of shoot meristem activity [23] [27] [29]. These authors also suggest that this process is linked to the decrease in the concentration of gibberellins (GA) and the increase in the concentration of abscisic acid (ABA). Detailed descriptions of the effect of $A B A$ on the metabolism and responses to abiotic stress were published by [31].

The effect of increase in ABA concentration has been correlated with the expression of genes that indicate accumulation of sugars and phenolic compounds [19]. However, other hormones are interrelated and act con-

\section{Table 3. Winkler's index and precipitation during phenological events for Cabernet Sauvignon in different seasons.}

\begin{tabular}{cccccccccc}
\hline & \multicolumn{3}{c}{ Thermal Sum $\left({ }^{\circ} \mathrm{C}\right)$-Winkler's index } & \multicolumn{4}{c}{ Rainfall (mm) } \\
\cline { 2 - 9 } & $2005 / 2006$ & $2006 / 2007$ & $2008 / 2009$ & $2011 / 2012$ & $2005 / 2006$ & $2006 / 2007$ & $2008 / 2009$ & $2011 / 2012$ \\
\hline Budbreak-Flowering & 276.6 & 227.8 & 278.4 & 172.1 & 378.9 & 304.9 & 501.8 & 153.2 \\
Flowering-Veraison & 496.1 & 538.9 & 514.4 & 502.3 & 305.8 & 322.4 & 877.2 & 416.4 \\
Veraison-Harvest & 415.1 & 556.0 & 332.4 & 389.6 & 109.7 & 449.1 & 95.0 & 141.4 \\
Budbreak-Harvest & 1187.8 & 1322.7 & 1125.2 & 1063.9 & 794.4 & 1076.4 & 1474.0 & 711.0 \\
\hline
\end{tabular}

*Indicate $\sum[($ Maximum temperature + Minimum temperature)/2] - 10. 
junctively with ABA in the regulation of ripening [19]. [32] noted a significant effect between early cessation of the vegetative growth of the shoots and the concentration of malic acid, anthocyanins, and polyphenols in the composition of the grapes. Therefore, there is a link between the regions where the grapevines cease growth during ripening and the quality of the grapes and wine produced. Such conditions are favorable for the accumulation of sugars and phenolic compounds, which results in berries with higher levels of soluble solids and wines with more intense color and structure. These descriptions are in agreement with the results noted in this present study and with those reported by other authors who conducted studies in the São Joaquim region and noted high color intensity and high content of total phenolic compounds and anthocyanins in grapes [5] [6] [8] and wines [9].

Shoot length was established according to the polynomial model in the 2006/2007 cycle, where a period of slower growth was noted in the first few weeks after budbreak, showing a linear growth after 20 days and a decrease in the development after approximately 110 days. In the véraison phase (close to 130 days after budbreak) the shoots reduced development and ceased growth during berry ripening (Figure 6). After budbreak, growth rate values were low $(<5.0 \mathrm{~cm} /$ week $)$, and close to the $45^{\text {th }}$ day these values increased to around $25.0 \mathrm{~cm}$ per week (36 mm/day). From 110 days after budbreak onwards, the steady decline in the levels of shoot growth resulted in values similar to those of the initial growth phase. In this cycle, such behavior was also observed during the investigation on shoot growth of the variety Merlot [12]. These authors showed that growth cessation of the shoots for Cabernet Sauvignon also occurred during the onset of berry ripening in the 2008/2009 cycle.

During the 2011/2012 cycle, shoot growth in the varieties Sauvignon Blanc and Merlot showed a pattern similar to that described for Cabernet Sauvignon in 2006/2007 and 2008/2009 cycles. Although there were different values for shoot length, the results indicated that the cessation of vegetative growth occurred during berry ripening for all the varieties (Figure 6 and Figure 7). This observation is in agreement with the findings reported by [11] [32] who considered that the shoots ceased growth when the growth rate was less than $5 \mathrm{~mm} /$ day, which is what occurs during berry ripening in different vineyards of France. In both the cycles that were investigated, decrease in photoperiod and low temperatures $\left(<10^{\circ} \mathrm{C}\right)$ were the determining factors for the induction of growth cessation of the shoots in São Joaquim [12].

In this cycle, the growth rate of the shoots was more constant, with maximum values of $2.4 \mathrm{~cm} /$ day for the variety Sauvignon Blanc and over $3.7 \mathrm{~cm} /$ day for the red varieties (Figure 8). This maximum growth rate occurred in late November, about a week after full bloom (60 days after budbreak). In the red varieties, shoot growth cessation was noted in late February and in the Sauvignon Blanc, the shoots ceased growth in early March.

With the onset of berry ripening, the shoots started to lignify, the apex of the shoots and the side shoots ceased growth, and the leaves entered senescence. This observation is consistent with the description reported by [28] on the activation of the dormancy onset mechanism. The results of this present study are consistent with those obtained by [23], who concluded that a decrease in photoperiod induces a decrease in shoot growth, and by [27], who reported the simultaneous effect of photoperiod and temperature on the induction of dormancy.

\subsection{Ecophysiological Behavior of the Grapevines in São Joaquim, Brazil}

Figure 9 and Figure 10 summarize some of the events related to the vegetative growth of vines and to the ri-

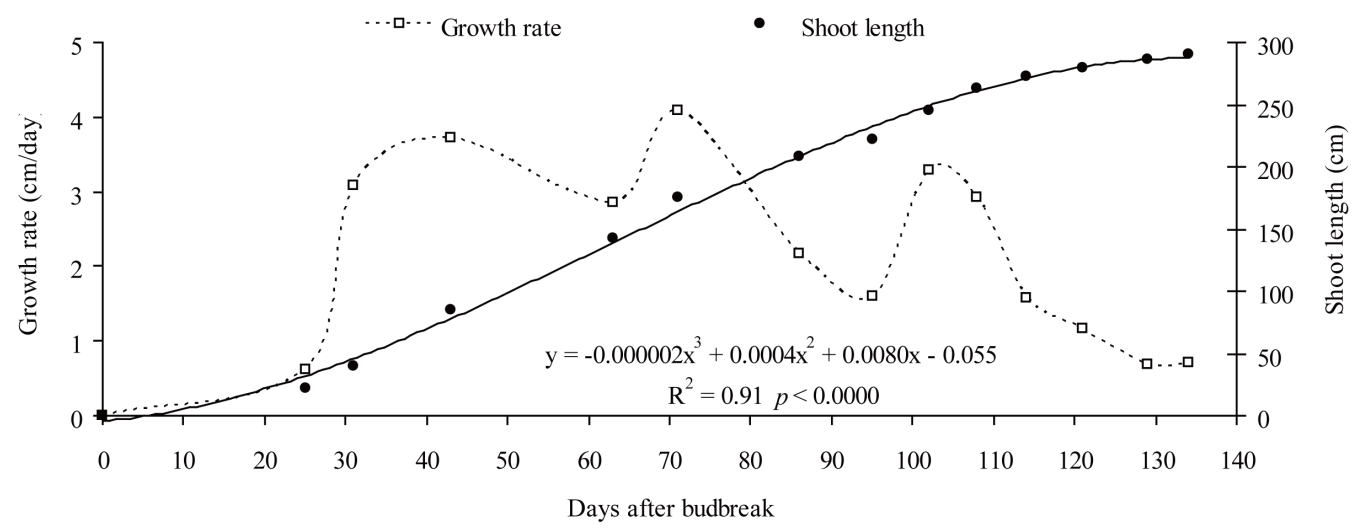

Figure 6. Length and growth rates of shoots of “Cabernet Sauvignon”, during the 2006/2007 season. 


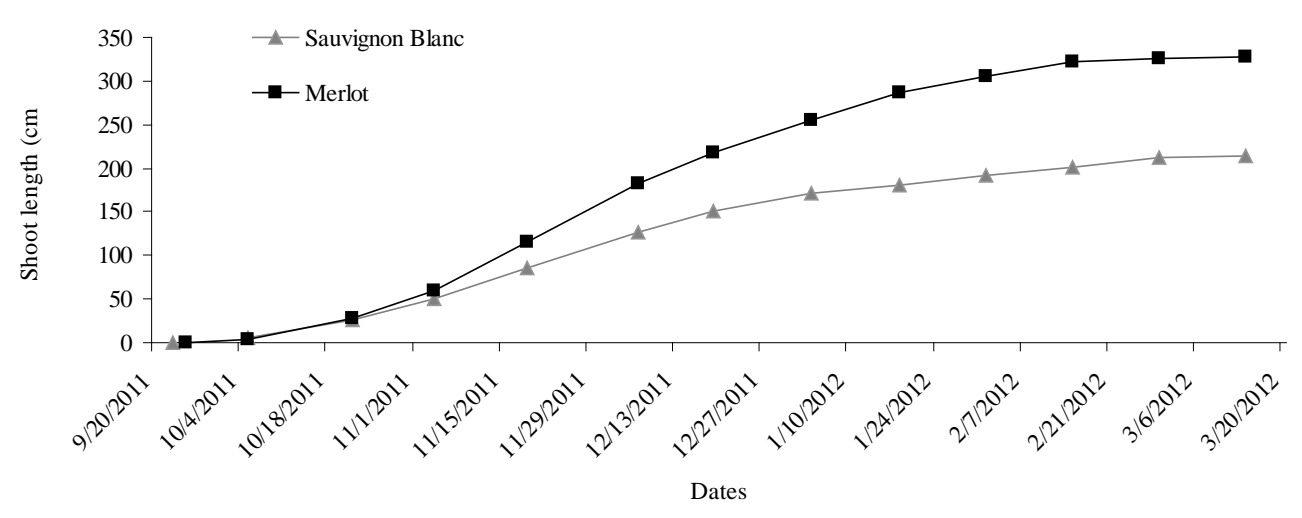

Figure 7. Shoot length of "Sauvignon Blanc" and "Merlot”, during the 2011/2012 season.

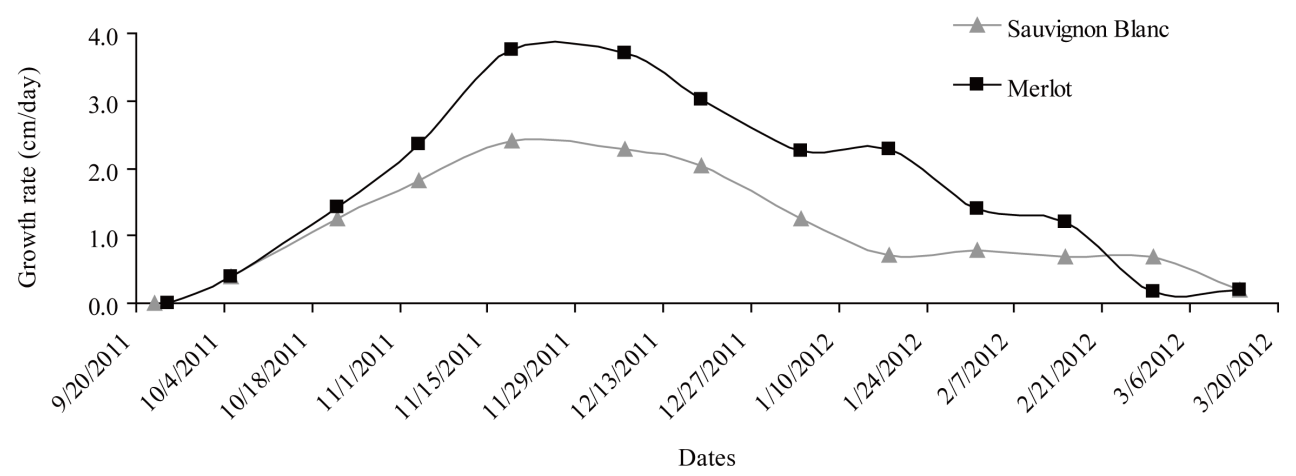

Figure 8. Shoot growth rate of "Sauvignon Blanc" and "Merlot”, during the 2011/2012 season.

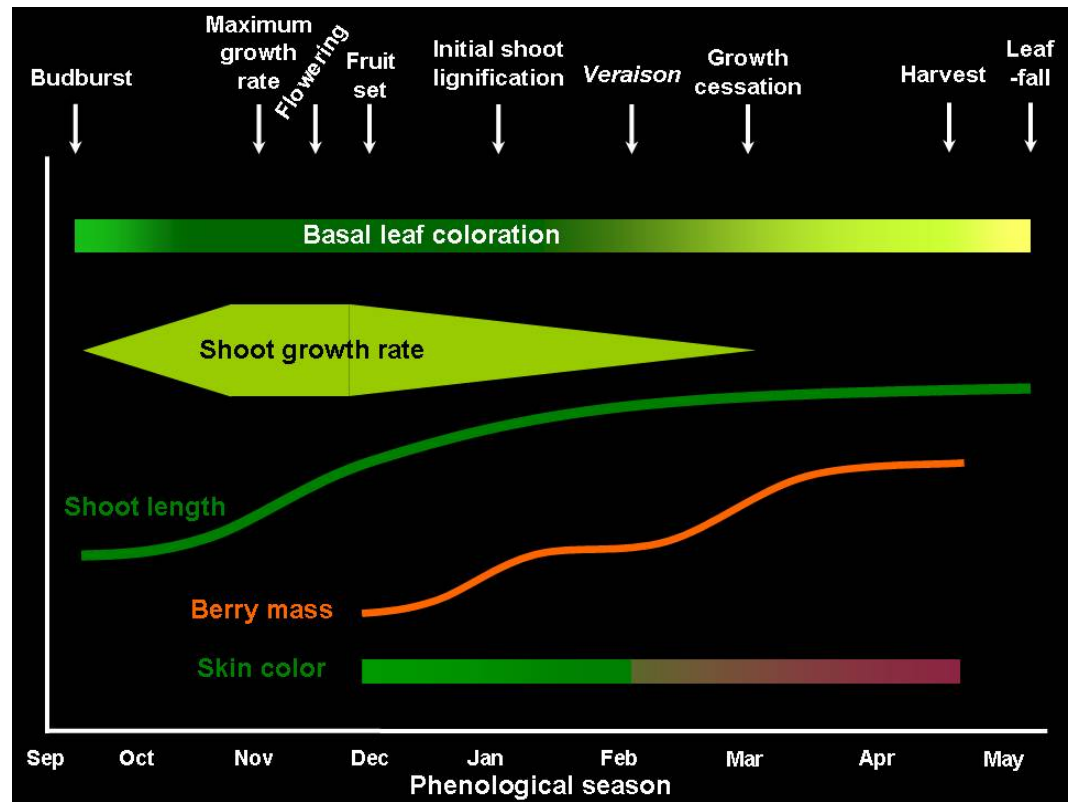

Figure 9. Relationships between vegetative growth and changes in growth and composition of the berries during phenological stage of "Merlot" and "Cabernet Sauvignon” in São Joaquim, SC, Brazil.

pening of grapes grown in São Joaquim. Based on observations in different cycles, the phenological stage and some key ecophysiological events related to plant growth and changes in the composition of the grapes were 


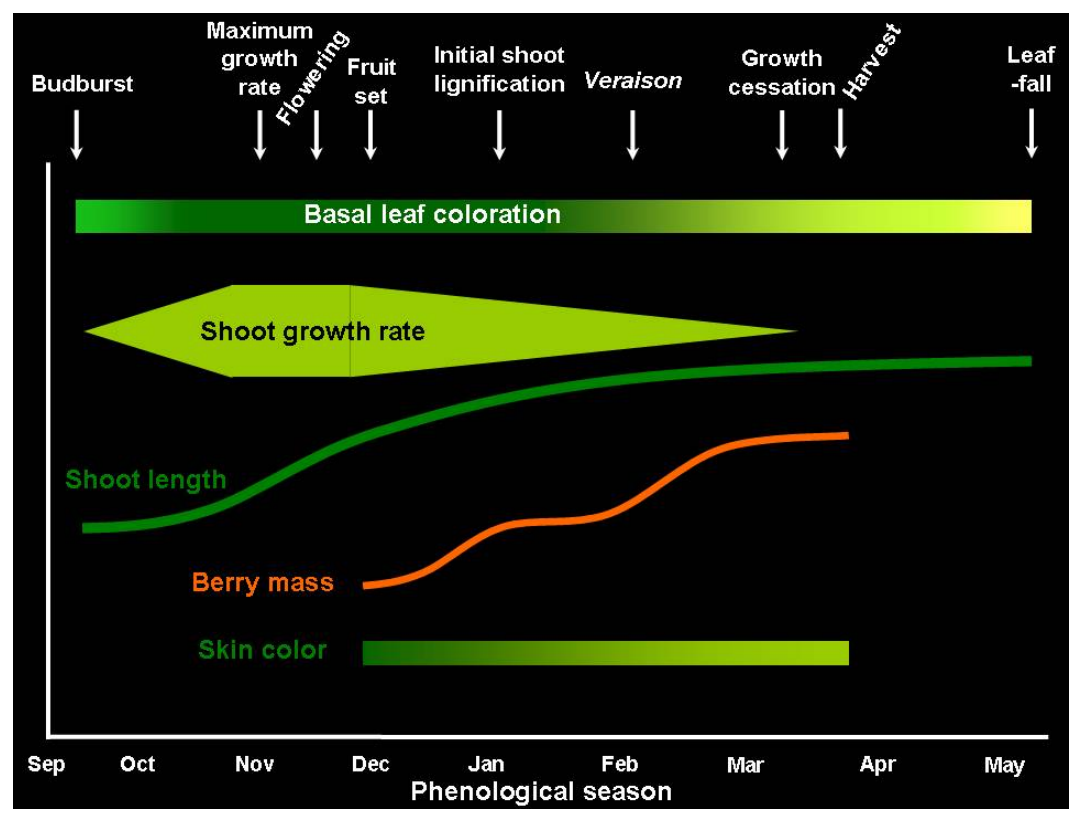

Figure 10. Relationships between vegetative growth and changes in growth and composition of the berries during phenological stage of "Sauvignon Blanc" in São Joaquim, SC, Brazil.

classified for the white and for the red varieties. The phenological stage is shown in relation to growth and ripening, which are presented according to the months of the year. Budbreak occurs in September, with variations between cycles due to accumulation of chilling units in the winter and the occurrence of temperatures above the base temperature $\left(10^{\circ} \mathrm{C}\right)$. Maximum shoot growth occurs a little before the flowering stage, which marks the end of the first growth phase. In this period, the shoots and the basal leaves begin to grow and it is possible to note the development of inflorescence and the formation of flowers. The chlorophyll levels in the basal leaves are already stabilized and possibly the photosynthetic capacity is already fully developed.

The development of bunches after flowering starts a competitive phase among the sinks (growth meristems and bunches), resulting in a gradual decrease in the growth rate of the shoots. The development of the berries comprises the steps of cell division and elongation, generating increase in cell number and in cell volume. The development of the seeds also begins during this period. After the onset of berry ripening, there are important changes in the composition of the grapes (mass of the berries, levels of sugars, organic acids, and phenolic compounds) and shoot growth (cessation of shoot growth). These events occur in February, when there is the occurrence of nighttime temperatures (minimum) below $10^{\circ} \mathrm{C}$ and a significant decrease in the photoperiod.

Lignification of the shoots and degradation of chlorophyll also occur during the onset of ripening. Regarding the climate characteristics, from February onwards there is a decrease in rainfall, a condition which enables the progress of berry ripening. In this region, the berries are exposed to lower temperatures, which favor slower processes, resulting in grapes with more advanced stages of ripening. The Sauvignon Blanc is harvested earlier in comparison to the red varieties (Cabernet Sauvignon and Merlot). The harvest of the white variety occurs in mid-March, near the time when cessation of shoot growth occurs. As for the red varieties, berry ripening extends until April. From March onwards there is the decrease in chlorophyll content and the progress of leaf senescence, initially in the leaves at the base of the shoots.

From April onwards, the temperatures are lower and there are occasional frosts. During this period, the shoots are completely lignified, the basal leaves are in an advanced state of senescence and the apical leaves show a more significant decrease in green color. The time of leaf senescence onset coincides with the berry ripening period, where there is a high demand for photoassimilates (Figure 11). With the progress of ripening, the demand on the sinks and the activity in the source organs decrease, and there is also a decrease in photosynthesis and degradation of photosynthetic pigments during leaf senescence. Between late May and early June the leaves fall completely. In this region, several aspects related to the vegetative growth of the grapevine still need to be elucidated, as well as the events for the period of development and ripening of the grapes. 

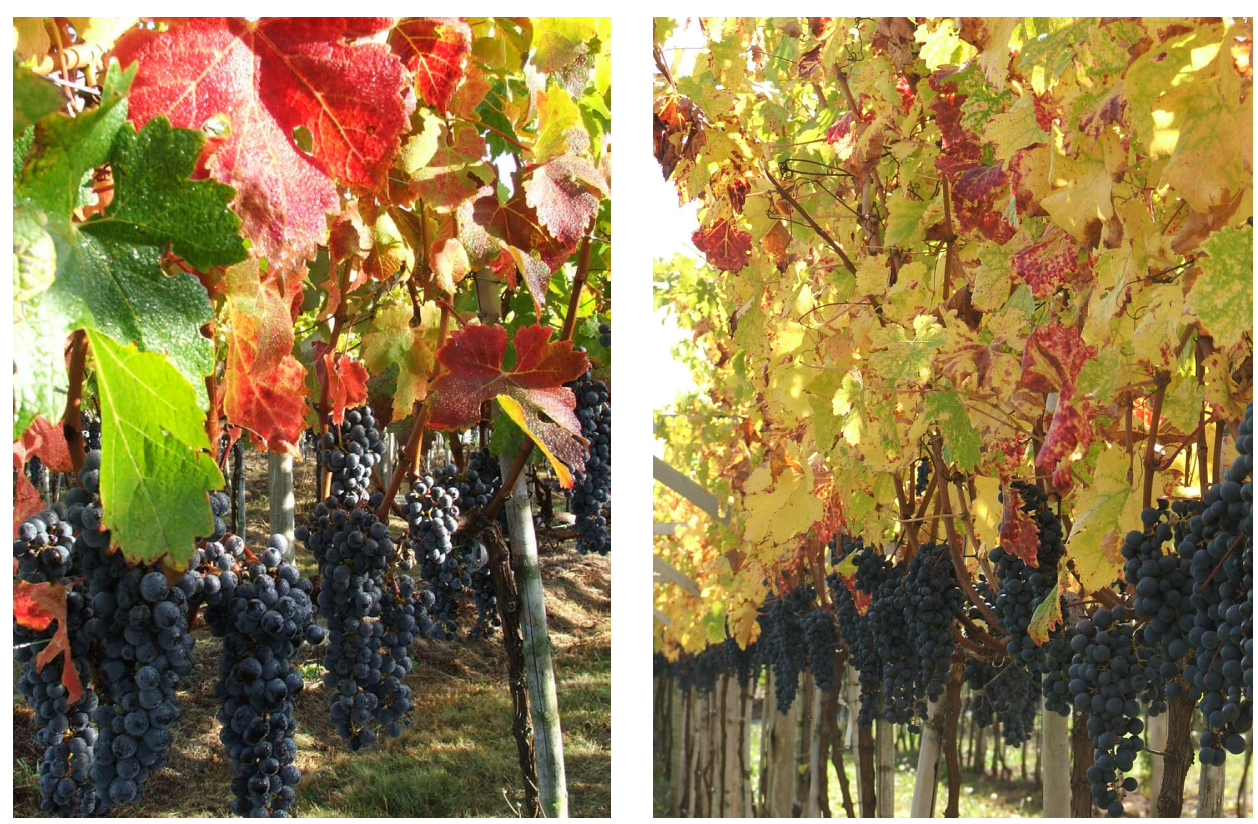

Figure 11. Canopy and bunches of “Cabernet Sauvignon” at harvest in 2006, in São Joaquim, SC, Brazil.

These models are not strictly appropriate for all varieties, also variations among vineyards, management systems, and even between different production seasons. Many aspects of plant development and physiology still need to be investigated as well as many events related to the berry ripening.

\section{Conclusion}

The grape varieties grown in the region of São Joaquim adapt to the local climate and soil conditions. The dormancy period is stable and the thermal needs for budbreak and for onset of vine growth are met in late winter. The phenological stage is stable between different production cycles and occurs later in relation to other winegrowing regions in Brazil. Shoot growth cessation occurs during the early stages of berry ripening and favors the composition of the grapes. Berry ripening occurs in a period of favorable weather conditions (cool temperatures and little rainfall). The geographic location in a lower latitude and its high altitude results in a distinct growing climate compared to the other winegrowing regions in Brazil. All these aspects mean that the varieties Sauvignon Blanc, Merlot and Cabernet Sauvignon show high grape quality at harvest, characteristics that are manifested in these wines.

\section{Acknowledgements}

The authors are thankful to the CAPES (Coordination for the Improvement of the Higher Level Personnel, Brazil) for their financial support for the field collections and for the postdoctoral scholarships. To Villa Francioni for permitting the use of the vineyard for investigation. To CIRAM (Center of Environmental Resources Information and Hydrometeorology of Santa Catarina) for meteorological data.

\section{References}

[1] Leeuwen, C. and Seguin, G. (2006) The Concept of Terroir in Viticulture. Journal of Wine Research, 17, 1-10. http://dx.doi.org/10.1080/09571260600633135

[2] Mello, L.M.R. (2012) Vitivinicultura Brasileira: Panorama 2011. Bento Gonçalves, 4 p. (Comunicado Técnico 115).

[3] Tonietto, J. and Carbonneau, A. (2004) A Multicriteria Climatic Classification System for Grape-Growing Regions Worldwide. Agricultural and Forest Meteorology, 124, 81-97. http://dx.doi.org/10.1016/j.agrformet.2003.06.001

[4] Rosier, J.P. (2003) Novas Regiões: Vinhos de altitude no sul do Brasil. In: X Congresso Brasileiro de Viticultura e Enologia, Anais, Bento Gonçalves, 137-140. 
[5] Falcão, L.D., Chaves, E.S., Burin, V.M., Falcão, A.P., Gris, E.F., Bonin, V. and Bordignon-Luiz, M.T. (2008) Maturity of Cabernet Sauvignon Berries from Grapevines Grown with Two Different Training Systems in a New Grape Growing Region in Brazil. Ciencia e Investigación Agraria, 35, 271-282. http://dx.doi.org/10.4067/S0718-16202008000300010

[6] Gris, E.F., Burin, V.M., Brighenti, E., Vieira, H. and Bordignon-Luiz, M.T. (2010) Phenology and Ripening of Vitis vinifera L. Grapes Varieties in São Joaquim, Southern Brazil: A New South American Wine Growing Region. Ciencia e Investigación Agraria, 37, 61-75. http://dx.doi.org/10.4067/S0718-16202010000200007

[7] Borghezan, M., Gavioli, O., Pit, F.A. and Silva, A.L. (2011) Comportamento vegetativo e produtivo da videira e composição da uva em São Joaquim, Santa Catarina. Pesquisa Agropecuária Brasileira, 46, 398-405. http://dx.doi.org/10.1590/S0100-204X2011000400009

[8] Burin, V.M., Silva, A.P., Malinovski, L.I., Rosier, J.P., Falcão, L.D. and Bordignon-Luiz, M.T. (2011) Characterization and Multivariate Classification of Grapes and Wines of Two Cabernet Sauvignon Clones. Pesquisa Agropecuária Brasileira, 46, 474-481.

[9] Miele, A., Rizzon, L.A. and Zanus, M.C. (2010) Discrimination of Brazilian Red Wines According to the Viticultural Region, Varietal, and Winery Origin. Ciência e Tecnologia de Alimentos, 30, 268-275. http://dx.doi.org/10.1590/S0101-20612010000100039

[10] Blanco-Ward, D., Queijeiro, J.M.G. and Jones, G. (2007) Spatial Climate Variability and Viticulture in the Miño River Valley of Spain. Vitis, 46, 63-70.

[11] Leeuwen, C., Friant, P., Choné, X., Trégoat, O., Koundouras, S. and Dubourdieu, D. (2004) The Influence of Climate, Soil and Cultivar on Terroir. American Journal of Enology and Viticulture, 55, 207-217.

[12] Borghezan, M., Gavioli, O., Vieira, H.J. and Silva, A.L. (2012) Shoot Growth of Merlot and Cabernet Sauvignon Grapevine Varieties. Pesquisa Agropecuária Brasileira, 47, 200-2007.

[13] Camargo, C.G.C., Braga H.J., Malandrin, D. and Machado, L. (2011) Análises de Eventos Extremos de Precipitação na Região Sul do Brasil: Dados Históricos. In: XVII Congresso Brasileiro de Agrometeorologia, Anais, Guarapari, CDRom.

[14] Jones, G. and Davis, R.E. (2000) Climate Influences on Grapevine Phenology, Grape Composition, and Wine Production and Quality for Bordeaux, France. American Journal of Enology and Viticulture, 51, 249-261.

[15] Duchêne, E. and Schneider, C. (2005) Grapevine and Climatic Changes: A Glance at the Situation in Alsace. Agronomy for Sustainable Development, 25, 93-95. http://dx.doi.org/10.1051/agro:2004057

[16] Coombe, B.G. (1995) Growth Stages of the Grapevine: Adoption of a System for Identifying Grapevine Growth Stages. Australian Journal of Grape and Wine Research, 1, 104-110. http://dx.doi.org/10.1111/j.1755-0238.1995.tb00086.x

[17] Lorenz, D.H., Eichhorn, K.W., Bleiholder, H., Klose, R., Meier, U. and Weber, E. (1995) Growth Stages of the Grapevine: Phenological Growth Stages of the Grapevine (Vitis vinifera L. ssp. vinifera) —Codes and Descriptions According to the Extended BBHC Scale. Australian Journal of Grape and Wine Research, 1, 100-103. http://dx.doi.org/10.1111/j.1755-0238.1995.tb00085.x

[18] Lavee, S. and May, P. (1997) Dormancy of Grapevine Buds-Facts and Speculation. Australian Journal of Grape and Wine Research, 3, 31-46. http://dx.doi.org/10.1111/j.1755-0238.1997.tb00114.x

[19] Conde, C., Fontes, N., Dias, A.C.P., Tavares, R.M., Souza, M.J., Agasse, A., Delrot, S. and Gerós, H. (2007) Biochemical Changes throughout Grape Berry Development and Fruit and Wine Quality. Food, 1, 1-22.

[20] Brighenti, E. and Bonin, V. (2008) Comportamento fenológico de cultivares de videira (Vitis vinifera), na região de São Joaquim, SC. In: VIII Seminário Nacional sobre Fruticultura de Clima Temperado, Anais, São Joaquim, 65-70.

[21] Mandelli, F., Tonietto, J., Camargo, U.A. and Czermainski, A.B.C. (2004) Fenologia e necessidade térmicas da videira na Serra Gaúcha. In: XVIII Congresso Brasileiro de Fruticultura, Anais, Florianópolis, 4 p.

[22] Mota, C.S., Amarante, C.V.T., Santos, H.P. and Zanardi, O.Z. (2008) Comportamento vegetativo e produtivo de videiras “cabernet sauvignon” cultivadas sob cobertura plástica. Revista Brasileira de Fruticultura, 30, 148-153. http://dx.doi.org/10.1590/S0100-29452008000100027

[23] Garris, A., Clark, L., Owens, C., Mckay, S., Luby, J., Mathiason, K. and Fennell, A. (2009) Mapping of PhotoperiodInduced Growth Cessation in the Wild Grape Vitis riparia. Journal of the American Society for Horticultural Science, 134, 261-272.

[24] Petrie, P.R., Trought, M.C.T. and Howell, G.S. (2000) Fruit Composition and Ripening of Pinot Noir (Vitis vinifera L.) in Relation to Leaf Area. Australian Journal of Grape and Wine Research, 6, 46-51. http://dx.doi.org/10.1111/j.1755-0238.2000.tb00161.x

[25] Hunter, J.J, Volschenk, C.G., Marais, J. and Fouché, G.W. (1988) Composition of Sauvignon Blanc Grapes as Affected by Pre-Véraison Canopy Manipulation and Ripeness Level. South African Journal of Enology and Viticulture, 9, 3-9. 
[26] Dufourcq, T. and Bonnisseau, M. (2003) Adaptation de la conduite du vignoble: La gestion du rapport feuilles/fruits. Institut Français de la Vigne et du Vin, 10 p.

[27] Tanino, K.K., Kalcsits, L., Silim, S., Kendall, E. and Gray, G.R. (2010) Temperature-Driven Plasticity in Growth Cessation and Dormancy Development in Deciduous Woody Plants: A Working Hypothesis Suggesting How Molecular and Cellular Function Is Affected by Temperature during Dormancy Induction. Plant Molecular Biology, 73, 49-65. http://dx.doi.org/10.1007/s11103-010-9610-y

[28] Victor, K.J., Fennell, A.Y. and Grimplet, J. (2010) Proteomic Analysis of Shoot Tissue during Photoperiod Induced Growth Cessation in V. riparia Michx. Grapevines. Proteome Science, 8, 1-17. http://dx.doi.org/10.1186/1477-5956-8-44

[29] Olsen, J.E. (2010) Light and Temperature Sensing and Signaling in Induction of Bud Dormancy in Woody Plants. Plant Molecular Biology, 73, 37-47. http://dx.doi.org/10.1007/s11103-010-9620-9

[30] Chao, W.S., Foley, M.E., Horvath, D.P. and Anderson, J.V. (2007) Signals Regulating Dormancy in Vegetative Buds. International Journal of Plant Developmental Biology, 1, 49-56.

[31] Cramer, G.R. (2010) Abiotic Stress and Plant Responses from the Whole Vine to the Genes. Australian Journal of Grape and Wine Research, 16, 86-93. http://dx.doi.org/10.1111/j.1755-0238.2009.00058.x

[32] Tregoat, O., Leeuwen, C.V., Choné, X. and Gaudillère, J.P. (2002) Étude du régime hydrique et de la nutrition azotée de la vigne par des indicateurs physiologiques: Influence sur le comportement de la vigne et la maturation du raisin (Vitis vinifera L. cv. Merlot, 2000, Bordeaux). Journal International des Sciences de la Vigne et du Vin, 36, 133-142. 